\title{
RANCANGAN RUMAH BELAJAR DALAM KONSEP KESEHARIAN DI KAWASAN PADEMANGAN BARAT
}

\author{
Yessica Fransisca ${ }^{1)}$, Rudy Surya ${ }^{21}$ \\ 1)Program Studi S1 Arsitektur, Fakultas Teknik, Universitas Tarumanagara, yessica.315160059@stu.untar.ac.id \\ 2) Program Studi S1 Arsitektur, Fakultas Teknik, Universitas Tarumanagara, rudys@ft.untar.ac.id
}

\begin{abstract}
Abstrak
Manusia tidak terlepas dari kegiatan ataupun aktivitas kesehariannya untuk mencapai suatu tujuan dalam kehidupannya. Bagaimana manusia dapat bertahan hidup dengan eksistensinya yang disebut berhuni. Dalam hal berhuni, arsitek berperan dalam membangun dan merancang suatu tempat atau bangunan untuk mewadahi kegiatan manusia tersebut. Semakin sulitnya perekonomian dan lapangan kerja ditambah lagi dengan tingginya taraf hidup di Jakarta, serta naiknya harga berbagai kebutuhan pokok mengakibatkan bertambahnya jumlah penduduk miskin di Jakarta. Pembangunan pendidikan seharusnya diutamakan karena suatu kemajuan bangsa dapat dilihat dari kemajuan pendidikan. Metode perancangan arahan yang digunakan adalah everydayness. Arahan ini adalah menghasilkan sebuah karya dalam arsitektur yang lebih manusiawi. Di mana seorang arsitek mendesain sebuah karya arsitektur dengan menganalisa bagaimana kehidupan keseharian dan juga kebutuhan apa yang diperlukan bagi manusia tersebut. Pademangan Barat merupakan salah satu kawasan yang masih kurangnya fasilitas pendidikan khususnya bagi anak-anak yang kurang mampu. Penyediaan Rumah Belajar dalam cangkupan pendidikan non-formal ini diperuntukkan untuk anak-anak yang kurang mampu yang mengalami kondisi kemiskinan di kawasan Pademangan Barat. Rumah Belajar menjadi rumah kedua bagi anak-anak, di mana mereka menghabiskan keseharian waktunya dan juga sebagai tempat untuk melayani sejumlah tujuan dalam kehidupan seorang anak. Dalam Rumah Belajar ini anak-anak berpeluang untuk menemukan tempat mereka di dunia ini melalui pencapain makhluk hidup terkait dengan berhuni. Konsep dari Rumah Belajar ini adalah menetapkan kehidupan dan sistem yang berkelanjutan, sehingga pengguna dalam Rumah Belajar ini dengan menjalankan tujuan dalam berhuni, namun pada bangunan dalam konteks arsitektur menetapkan sistem dan penggunaan material yang berkelanjutan, yang nantinya dapat membantu untuk kehidupan di masa depan.
\end{abstract}

Kata kunci: berhuni; kehidupan; masa depan; rumah belajar

\begin{abstract}
Every human wants to pursue their goal of life that is reflected in their daily activities. How humans can survive with their existence is called dwelling. An architect plays some roles in building and designing places or buildings for accommodating human activities as the term of dwelling. As the economics and employment getting worse and the high standard of living being added in Jakarta, also the increasing values of necessities causing the number of mendicant people in Jakarta getting more in numbers. Education development is a priority because the development of the nation can be seen from the development of education. Everydayness is used as a design approach method. This direction is to produce a work in a more humane architecture. Where an architect designs an architectural work by analyzing how everyday life is and what human needs are needed. As an area that lacks educational facilities, especially educational facilities for underprivileged children. The provision of Rumah Belajar in non-formal education programs is intended for underprivileged children who are experiencing poverty conditions in the West Pademangan area. Rumah Belajar becomes a second home for children, where they spend their daily time and also as a place to serve some purposes in a child's life. In this place, children have the opportunity to find a place for their world through the attainments of living things related to dwelling. The
\end{abstract}


concept of the Rumah Belajar is to establish a sustainable life as a system. So that users in this Rumah Belajar can carry out the purpose of dwelling, in the form of building in the architecture context. The architecture will determine as a sustainable system and materials, which can help the future of life.

\section{Keywords: dwelling; future; life; rumah belajar}

\section{PENDAHULUAN}

\section{Latar Belakang}

Berhuni tidak saja harus berada dalam sebuah ruangan yang terdapat lapisan atas berbentuk atap. Aktivitas manusialah yang membentuk sebuah ruangan tersebut. Konsep hunian tersebut digunakan untuk menyampaikan keberadaan manusia di dunia. Dan juga dengan menyesuaikan diri pada kehidupan untuk melanjutkan kehidupan di masa depan. Kehidupan berhuni di masa depan menetapkan beberapa visi untuk membuat kehidupan di masa depan yang lebih baik. Semakin sulitnya perekonomian dan lapangan kerja ditambah lagi dengan tingginya taraf hidup di Jakarta, serta naiknya harga berbagai kebutuhan pokok mengakibatkan bertambahnya jumlah penduduk miskin di Jakarta. Untuk mengatasi masalah tersebut, peranan pendidikan sangat dibutuhkan. Pembangunan pendidikan seharusnya diutamakan karena suatu kemajuan bangsa dapat dilihat dari kemajuan pendidikan.

Pademangan Barat merupakan salah satu kawasan yang masih kurangnya fasilitas pendidikan khususnya bagi anak-anak yang kurang mampu. Penyediaan Rumah Belajar dalam cangkupan pendidikan non-formal ini diperuntukkan untuk anak-anak yang kurang mampu yang mengalami kondisi kemiskinan di kawasan Pademangan Barat. Rumah Belajar menjadi rumah kedua bagi anak-anak, di mana mereka menghabiskan keseharian waktunya dan juga sebagai tempat untuk melayani sejumlah tujuan dalam kehidupan seorang anak. Seperti belajar, bertukar pikiran, ide, perasaan dan menerima sebuah nilai-nilai umum. Dalam Rumah Belajar ini anak-anak berpeluang untuk menemukan tempat mereka di dunia ini melalui pencapain makhluk hidup terkait dengan dwelling. Konsep dari Rumah Belajar ini adalah menetapkan kehidupan dan sistem yang berkelanjutan. Sehingga pengguna dalam Rumah Belajar ini dengan menjalankan tujuan dalam berhuni, namun pada bangunan dalam konteks arsitektur yang menetapkan sistem dan penggunaan material yang berkelanjutan. Sehingga dapat membantu untuk kehidupan di masa depan.

\section{Rumusan Permasalahan}

a. Bagaimana merancang sebuah rumah belajar yang mampu mewadahi anak-anak kurang mampu dengan kondisi kemiskinan di Pademangan barat?

b. Bagaimana menyusun program yang mampu mengakomodasi akitivtas produktif anak di rumah belajar?

c. Program apa saja yang akan didapatkan dalam pembelajaran non-formal di dalam Rumah Belajar tersebut?

d. Bagaimana Rumah Belajar dapat menampung anak-anak yang kurang mampu untuk mendapatkan suasana kenyamanan seperti rumah bagi mereka?

e. Bagaimana peran arsitektur pada Rumah Belajar terkait dengan berhuni di masa depan? 


\section{Tujuan}

Tujuan proyek ini adalah merancang sebuah wadah bagi anak-anak yang kurang mampu di kawasan Pademangan Barat berupa Rumah Belajar. Rumah belajar ini merupakan sarana pendidikan non-formal setingkat sekolah dasar yang sekaligus menjadi wadah berkumpul bersama bagi anak-anak dalam mengembangkan kebersamaan serta peningkatan kualitas kehidupan mereka.

\section{KAJIAN LITERATUR}

\section{Dwelling}

Kata "tinggal" di sini artinya sesuatu yang lebih dari sekedar memiliki atap di atas kepala kita ataupun sejumlah tertentu meter persegi yang kita miliki, tetapi yaitu: (Norberg, 1985)

- (Kolektif) Bertemu orang lain untuk bertukar produk, ide, dan perasaan, yaitu mengalami hidup sebagai banyak kemungkinan.

- (Publik) Mencapai kesepakatan dengan yang lain, yaitu menerima satu set nilai-nilai umum.

- (Pribadi) Menjadi diri sendiri, dalam arti memiliki dunia pilihan kecil kita sendiri.

Menggunakan konsep hunian untuk menyampaikan gagasan berada di dunia, yang melampaui gagasan kehadiran belaka, menunjukkan cara suatu entitas menunjukkan dirinya di dalam dunia (Heidegger, 1971). Hunian, selain ruang, juga dibentuk oleh waktu (Heidegger, 1962). Mengemukakan bahwa waktu yang dihabiskan di suatu tempat adalah bagian dari konteks relasional di mana orang terlibat di dunia. Memperkenalkan konsep "perspektif tempat tinggal" untuk menggarisbawahi keterlibatan aktif seseorang dengan konteks sekitarnya (Ingold, 2000).

Dwelling adalah fungsi yang bergantung pada peluang yang tersedia bagi siswa untuk menemukan tempat mereka di dunia melalui pencapaian makhluk dan perbuatan yang terkait dengan dwelling. Berfokus pada komponen waktu yang melekat, "tinggal dalam waktu" lebih lanjut mengacu pada kemampuan siswa untuk memposisikan diri mereka dalam hubungan yang menarik dan bermakna dalam waktu agar dapat berpikir dan membangun masa depan mereka (Sennett, 2018).

\section{Pendidikan}

Pendidikan merupakan kebutuhan manusia yang sangat penting karena pendidikan mempunyai tugas untuk menyiapkan SDM bagi pembangunan bangsa dan negara. Kemajuan ilmu pengetahuan dan teknologi (IPTEK) mengakibatkan perubahan dan pertumbuhan kearah yang lebih komplek. Hal ini menimbulkan masalah - masalah sosial dan tuntutan - tuntutan baru yang tidak dapat diramalkan sebelumnya, sehingga pendidikan selalu menghadapi masalah karena adanya kesenjangan antara yang diharapkan dengan hasil yang dapat dicapai dari proses pendidikan (Syah, 2004). Pendidikan non formal adalah setiap kesempatan dimana terdapat komunikasi yang terarah di luar sekolah dan seseorang memperoleh informasi, pengetahuan, latihan maupun bimbingan sesuai dengan tingkat usia dan kebutuhan hidup, dengan jutuan mengembangkan tingkat keterampilan, sikap dan nilai-nilai yang memungkinkan baginya menjadi peserta-peserta yang efesien dan efektif dalam lingkungan keluarga, pekerjaan bahkan lingkungan masyarakat dan negaranya (Soelaiman, 2004). 


\section{Pendidikan Dasar}

Menurut Jeffrey Sachs di dalam bukunya "The End of Proverty" salah satu mekanisme dalam penuntasan kemiskinan ialah pengembangan human capital terutama pendidikan dan kesehatan (Sachs, 2005:245-265). Penduduk usia sekolah memerlukan pelayanan pendidikan yang baik dan bermutu agar dapat survive dalam menjalani kehidupan di masa depan. Pendidikan dasar merupakan kerangka landasan bagi pendidikan lanjutan to lay the ground work for further education. Pendidikan dasar memberi sumbangan sangat besar, bahkan menentukan, dalam menyiapkan anak-anak untuk mengembangkan segenap potensi dan kemampuan mereka guna mengikuti pendidikan pada jenjang selanjutnya (Diatnika, 2009).

\section{Rumah Belajar}

Menurut KBBI, "rumah" berarti [1] bangunan untuk tempat tinggal dan [2] bangunan pada umumnya (seperti gedung). Padahal rumah tak sekadar kata benda. Rumah juga bisa menjadi kata sifat, sebab semua tahu pada bangunan bernama rumah itu terdapat berbagai hal yang biasa diklasifikasikan sebagai kata sifat: hangat, aman, nyaman, dll. Bahkan rumah juga memuat kandungan makna yang bisa diklasifikasi sebagai kata kerja, setidaknya perlu dikerjakan: hasrat, mimpi, cita-cita, dll (Zen, 2006).

\section{Community School}

Sekolah komunitas adalah sebagai tempat dan sekumpulan kemitraan, yang menghubungkan sekolah, keluarga siswa, dan masyarakat sekitar. Sekolah komunitas dibedakan oleh yang terintegrasi fokus pada akademisi, pengembangan pemuda, dukungan keluarga, kesehatan dan layanan sosial, dan pengembangan komunitas (Blank, Jacobson, \& Melaville, 2012). Sekolah komunitas dikembangkan untuk menawarkan pendidikan yang lebih baik bagi anak-anak tumbuh di lingkungan dan keluarga berpenghasilan rendah (Blank Et Al, 2012; Castrechini \& London, 2012). Sekolah komunitas secara khusus ditujukan untuk anak-anak yang menghadapi lebih banyak kesulitan sepanjang karir pendidikan mereka dan berbasis asumsi bahwa "ketidaksetaraan lebih berkaitan dengan kebijakan dan sosial / eko-struktur nomic daripada dengan karakteristik anak-anak individu dan keluarga mereka (Baquedano-Lopez, Alexander, \& Hernandez, 2013).

\section{METODE}

\section{Metode Riset}

Metode yang digunakan adalah metode pembahasan secara deskriptif dengan mengidentifikasi data-data dan teori terkait yang bersifat kualitatif dan kuantitatif yang kemudian dianalisa untuk memperoleh program dasar dengan peluang kombinasi dari program dasar tersebut. Pengumpulan data dilakukan dengan cara:

a. Studi literatur terkait teori, data, penelaahan, dan sejarah.

b. Melakukan survei dan observasi lapangan melalui penelitian dan pengamatan secara langsung terhadap objek atau proyek yang berkaitan.

c. Studi preseden, dengan membedah rancangan-rancangan yang nyata atau telah terbangun yang memiliki kemiripan program pada proyek yang diajukan. 


\section{Metode Perancangan}

Metode perancangan arahan yang digunakan dalam menyelesaikan permasalahan berhuni ini adalah everydayness. Arahan everydayness ini adalah menghasilkan sebuah karya dalam arsitektur yang lebih manusiawi. Di mana seorang arsitek mendesain sebuah karya arsitektur dengan menganalisa bagaimana kehidupan keseharian dan juga kebutuhan apa yang diperlukan bagi manusia tersebut. Manusia tidak telepas dari kegiatan atau aktivitas kesehariannya untuk mencapai tujuan dalam kehidupannya. manusia juga tidak terlepas dari kesalahan yang di mana kesalahan tersebut berkaitan dengan aktivitas kesehariannya. bagaimana manusia akan menghadapinya yaitu dengan cara beradaptasi dan kesalahan tersebut akan menjadi sebuah pengalaman untuk masa depannya.

\section{DISKUSI DAN HASIL}

\section{Kawasan dan Lokasi}

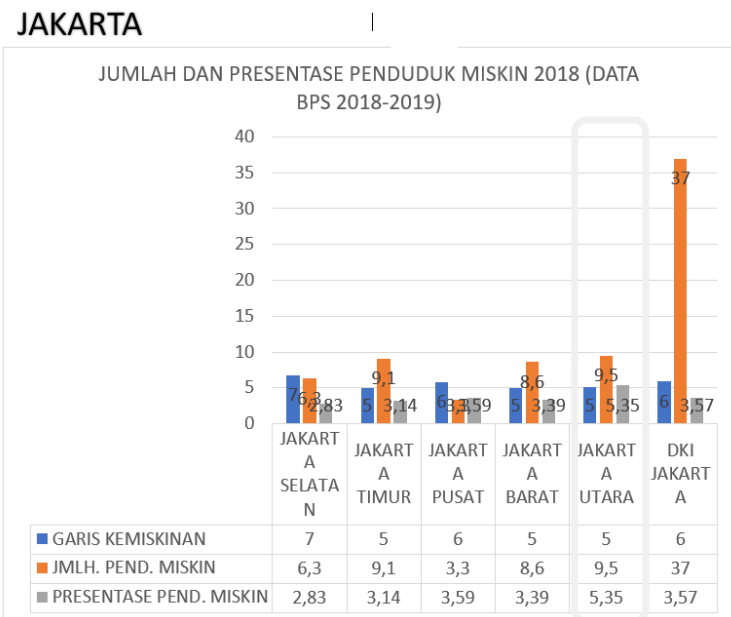

Tabel 1. Jumlah dan Presentase Penduduk Miskin Sumber: Badan Pusat Statistik (2018-2019)

Dari data tabel diatas terlihat bahwa, jumlah penduduk miskin di Jakarta mengalami peningkatan, terutama di wilayah Jakarta Utara. Meningkatnya jumlah penduduk miskin di Jakarta mengakibatkan banyaknya anak-anak dari keluarga yang mengalami kondisi kemiskinan, berhenti melanjutkan sekolahnya. Hal tersebut juga dikarenakan fasilitas sekolah yang kurang khususnya untuk anak- anak yang kurang mampu, dapat dilihat pada tabel 2.

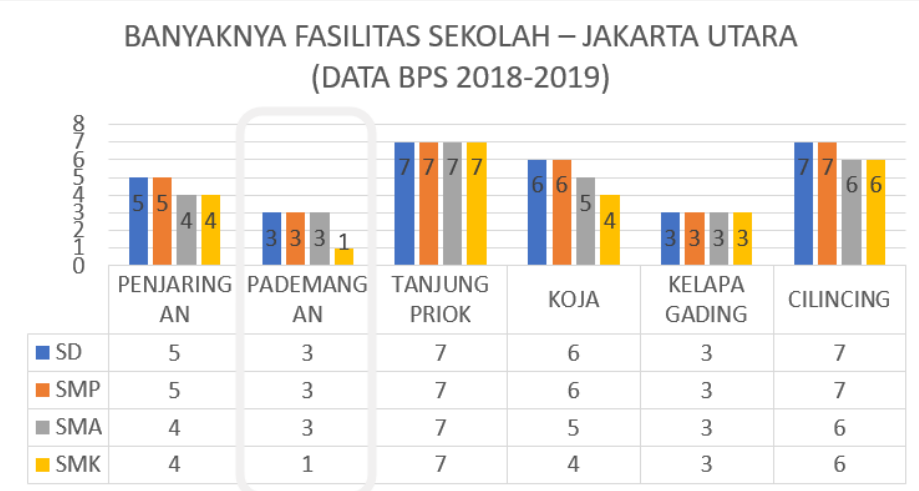

Tabel 2. Banyaknya Fasilitas Sekolah - Jakarta Utara Sumber: Badan Pusat Statistik (2018-2019) 
Dari tabel diatas terlihat bahwa, kurangnya fasilitas sekolah dari tingkat dasar sampai menengah atas, khususnya pada daerah Pademangan.

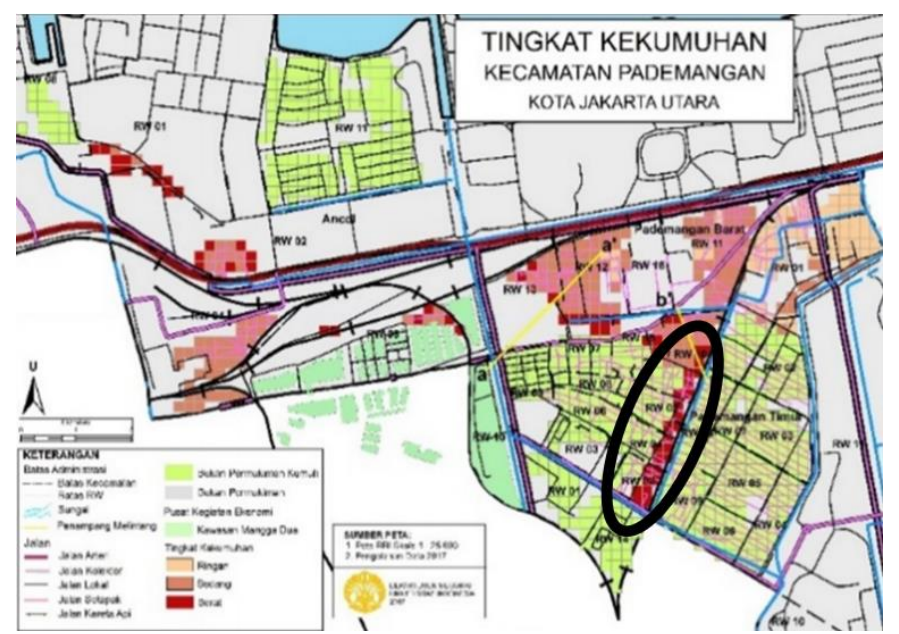

Gambar 1. Peta Tingkat Kekumuhan Kecamatan Pademangan Tahun 2017

Sumber: Prosiding Seminar NasionalPenelitian dan PKM Sosial, Ekonomi dan Humaniora (2017)

Pada gambar 1 terlihat bahwa pada warna merah yang dilingkari hitam menunjukkan daerah yang dinyatakan terkumuh. Walaupun data tercatat dari tahun 2017 namun di tahun 2020 ini daerah tersebut masih kumuh dan belum adanya perubahan. Bisa terlihat pada gambar 2 . Sehingga lokasi tapak yang dipilih berdekatan dengan daerah kumuh tersebut.

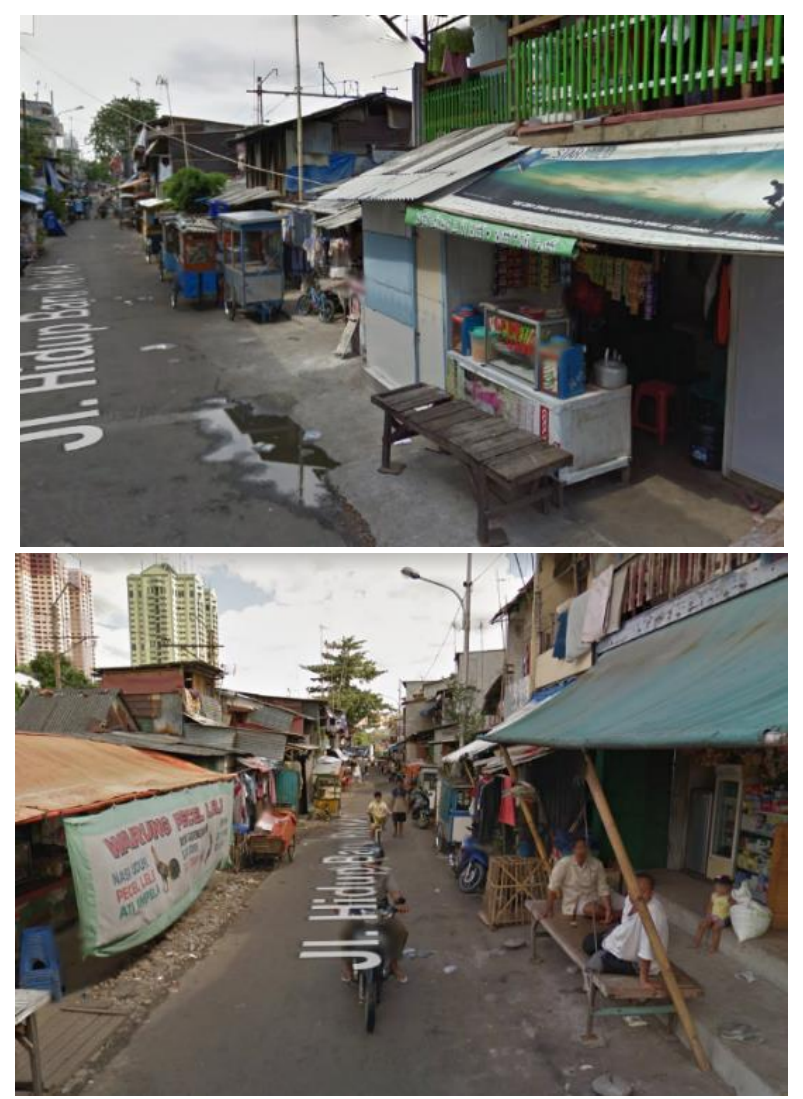

Gambar 2. Keadaan Existing Sekitar

Sumber: Google Maps (2020) 


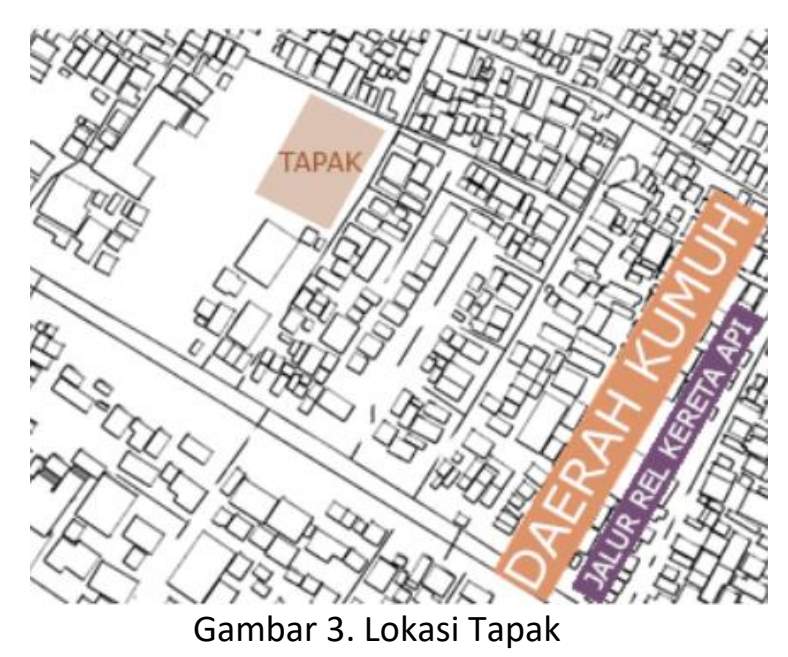

Sumber: Olahan Penulis (2020)

Lokasi tapak dipilih berdekatan dengan daerah paling kumuh di kawasan Pademangan Barat. Jarak yang ditempuh dari lokasi tapak dengan daerah kumuh tersebut, yaitu $\pm 350-400 \mathrm{~m}$ dan dengan waktu \pm 4-5 menit dengan jalan kaki. Sehingga anak-anak yang mengalami kondisi kemiskinan tersebut dapat bersekolah dengan jarak tempuh yang dekat dan mudah.

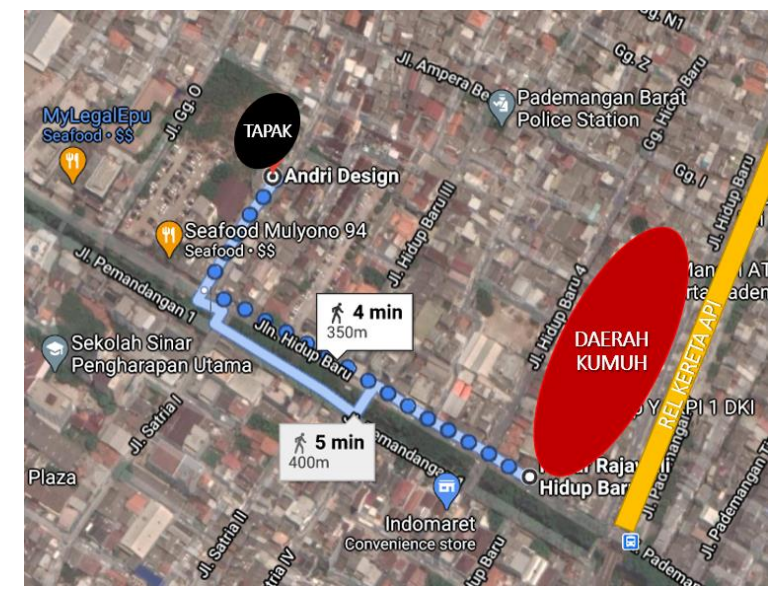

Gambar 4. Jalan Sekitar Tapak

Sumber: Olahan Penulis (2020) 


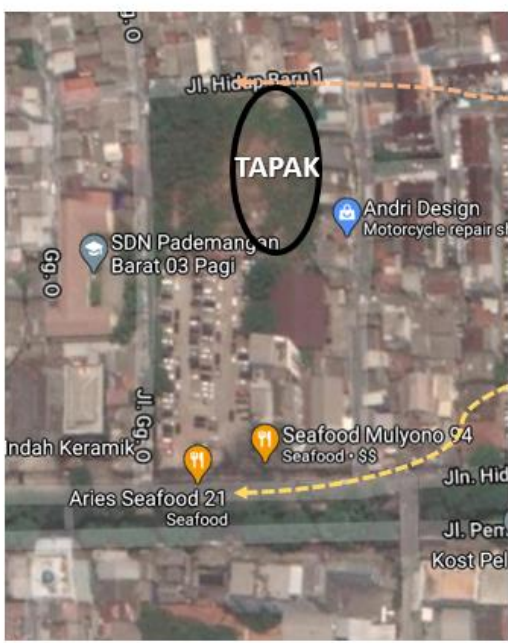

Gamber: Lohasi Tapalk Teps (2020)
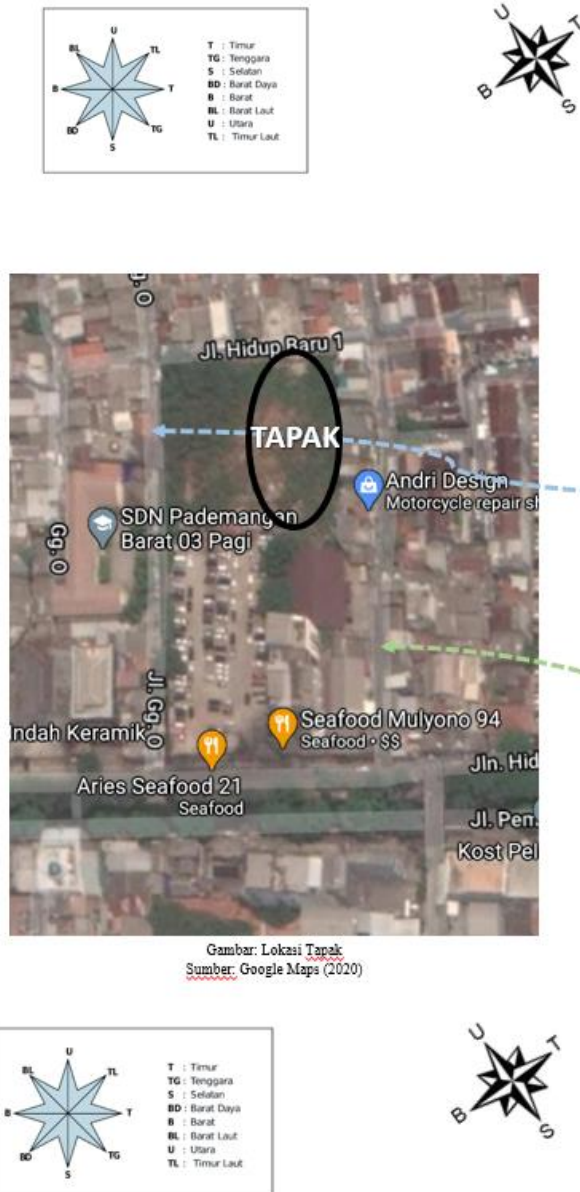

\section{BELAKANG TAPAK}

IL. HIDUP BARU 1

DENGAN LEBAR JALAN;

\pm 2 METER (HANYA BISA DILALUI

OLEH PEJALAN KAKI DAN MOTOR

SAJA)

\section{DEPAN TAPAK:}

Л. HIDUP BARU

DENGAN LEBAR JALAN:

\pm 6 METER (BISA DILALUI

KENDARAAN BERODA EMPAT) DAN

\pm 2 METER UNTUK TROTOAR

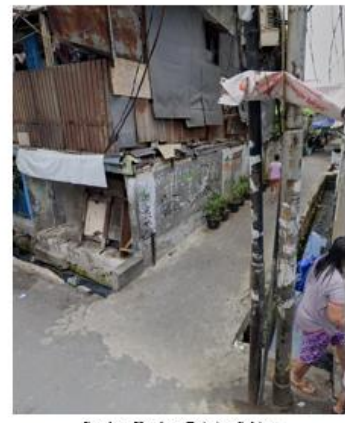

Gamber: Keadam Existing Sekitar
Sumber Google Maps (0200)

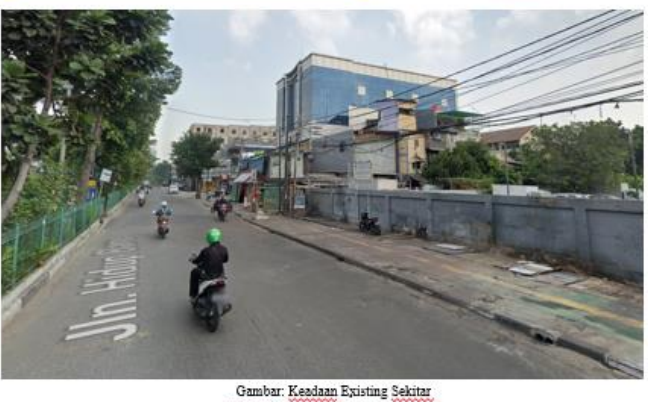

Gambar. Kesdan Existing Sekitar
Sumber. Sumber. Google Maps (2020)
SAMPING KIRI TAPAK

JL. GG O

DENGAN LEBAR JALAN

\pm 2 METER (HANYA BISA

DILALUI OLEH PEJALAN

KAKI DAN MOTOR SAJA)
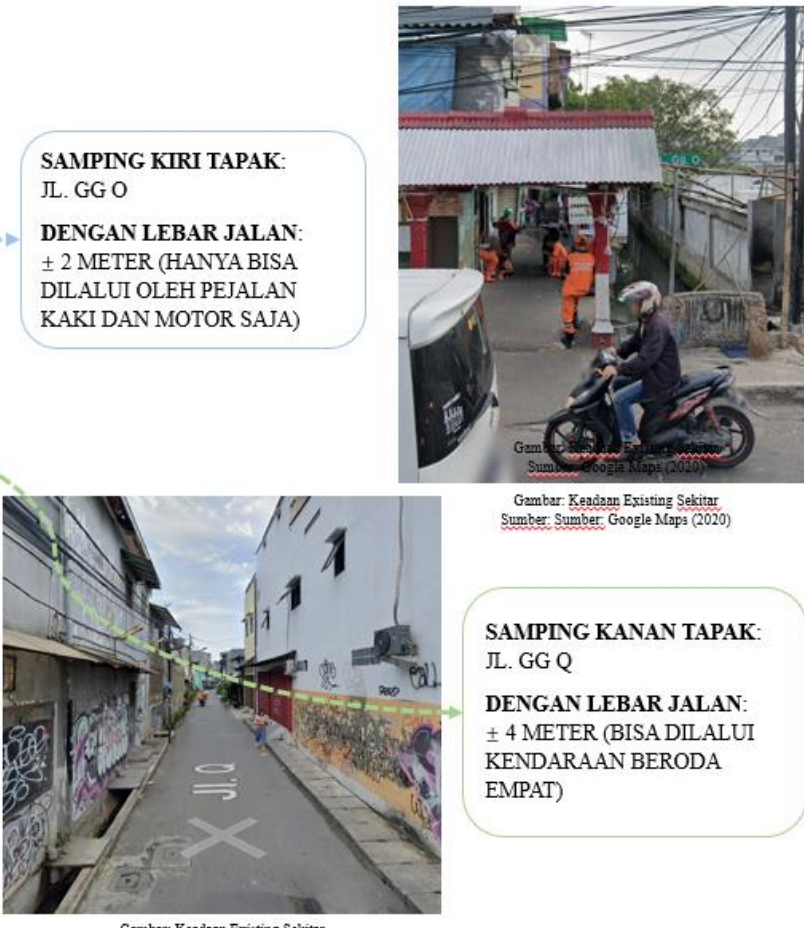

Gumber: Kegdann Existing Sekitar

Gembar: Kegdagan Existing Sekitar

AMPING KANAN TAPAK

JL. GG Q

DENGAN LEBAR JALAN:

\pm 4 METER (BISA DILALUI

KENDARAAN BERODA

EMPAT)
Gambar 5. Jalan Sekitar Tapak

Sumber: Olahan Penulis (2020) 


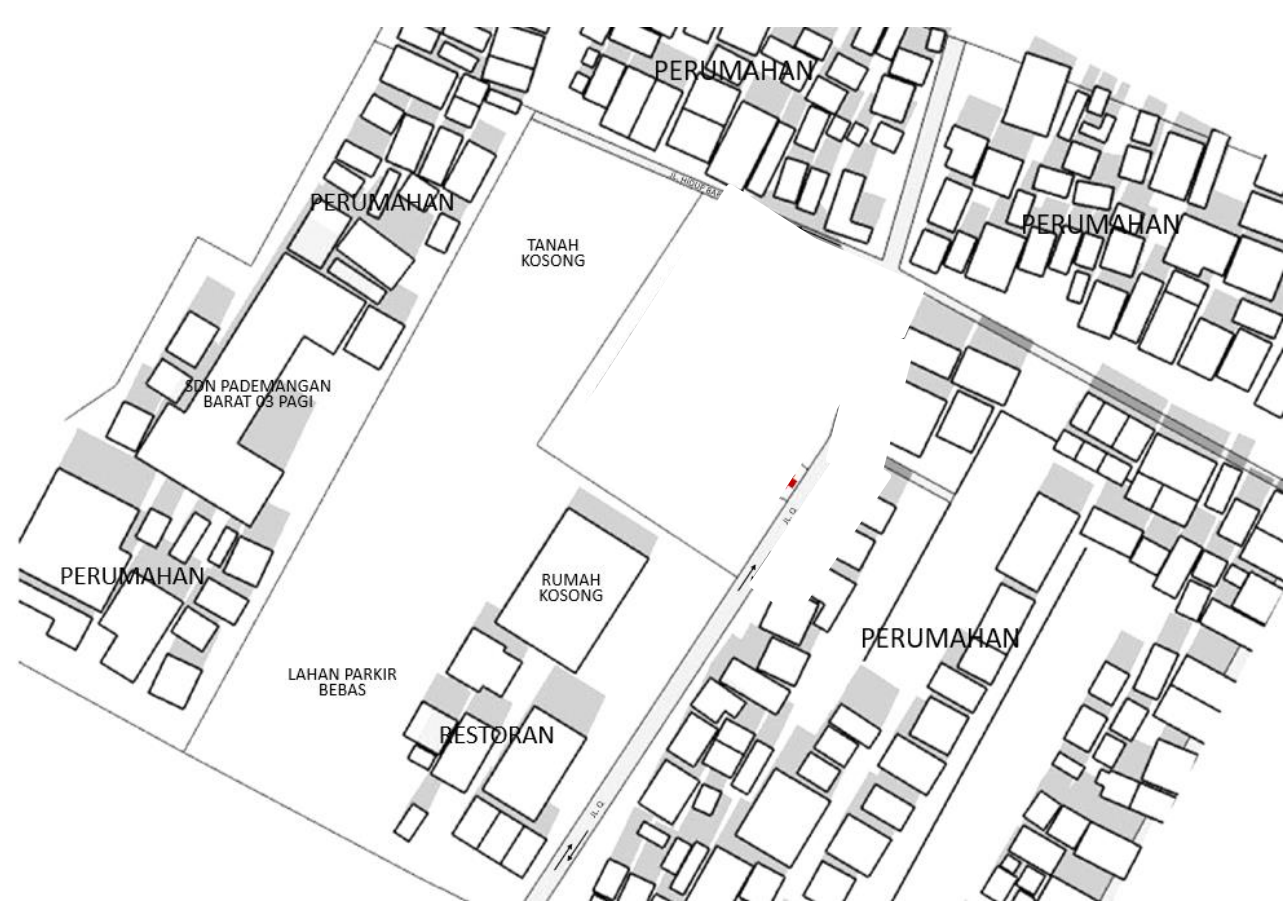

Gambar 6. Lokasi Tapak

Sumber: Olahan Penulis (2020)

Zonasi Peruntukan: Zona Perkantoran, Perdagangan, dan Jasa

Luas Tapak $: \pm 3.200 \mathrm{~m}^{2}$

$\mathrm{KDH}: 20$
KDB $: 60$
$\mathrm{KB}: 2$
KLB $: 1,2$

\section{Konsep dan Strategi Desain}

\section{KONSEP}

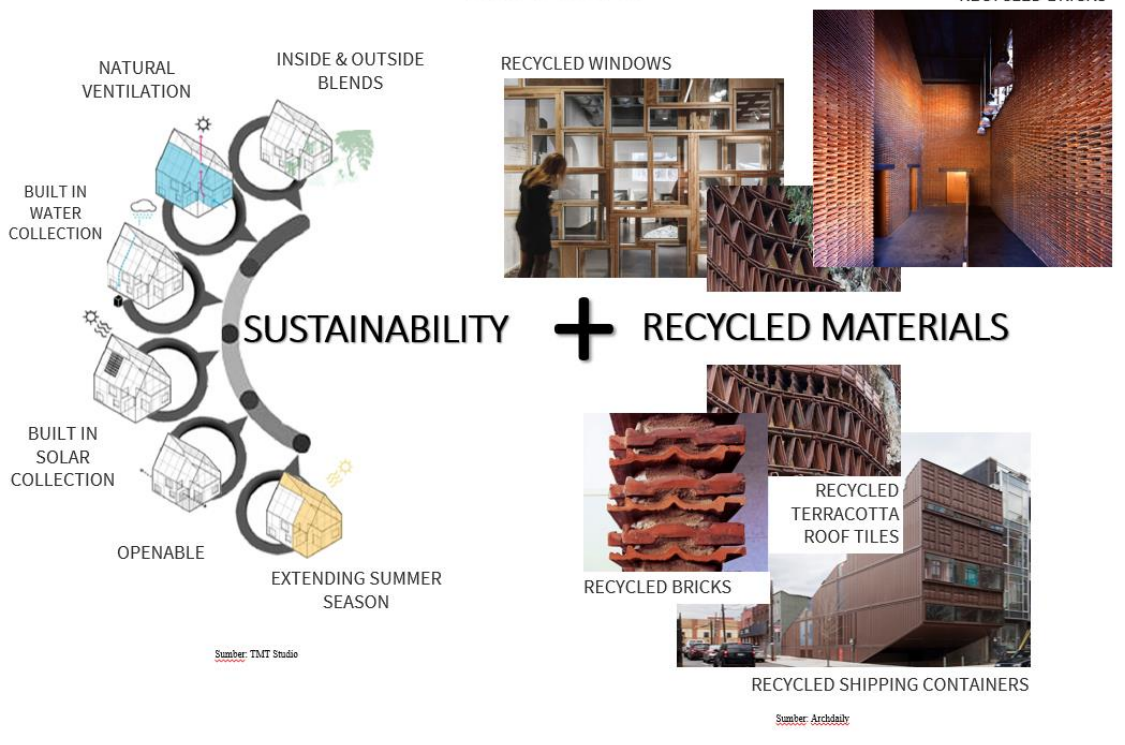

Gambar 7. Konsep

Sumber: Olahan Penulis (2020) 
Konsep yang diambil adalah Sustainability dan Recycled Materials, menggunakan material yang berkelanjutan seperti bambu, kayu dll. Bukaan atau jendela pada proyek bangunan menggunakan jendela bekas. Dengan konsep bangunan yang berkelanjutan sehingga dapat terjadinya pemeliharaan keseimbangan untuk kehidupan dan juga dapat membantu untuk kehidupan di masa depan. Material bekas yang digunakan pada bangunan, dapat mengurangi limbah sampah dan juga ramah lingkungan sehingga dapat mengurangi polusi udara.
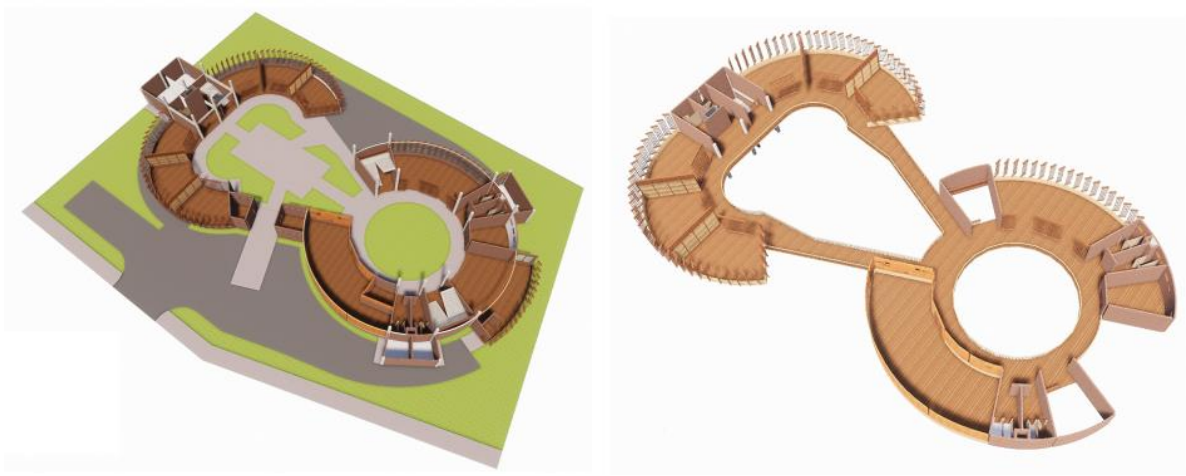

Gambar 8. Denah Lantai 1 dan 2 Sumber: Olahan Penulis (2020)

Pada gambar 8 yang merupakan denah lantai 1 dan 2, terlihat bahwa bangunan terdapat banyaknya dan dikelilingi oleh bukaan yang terbuat dari bambu, kayu, dan jendela bekas. Bangunan dibuat terbuka untuk terjadinya sirkulasi pengudaraan alami yang baik pada bangunan dan juga untuk pencahayaan alami. Sehingga bangunan dapat menghemat dalam penggunaan listrik, dengan alternatif menggunakan kipas angin.

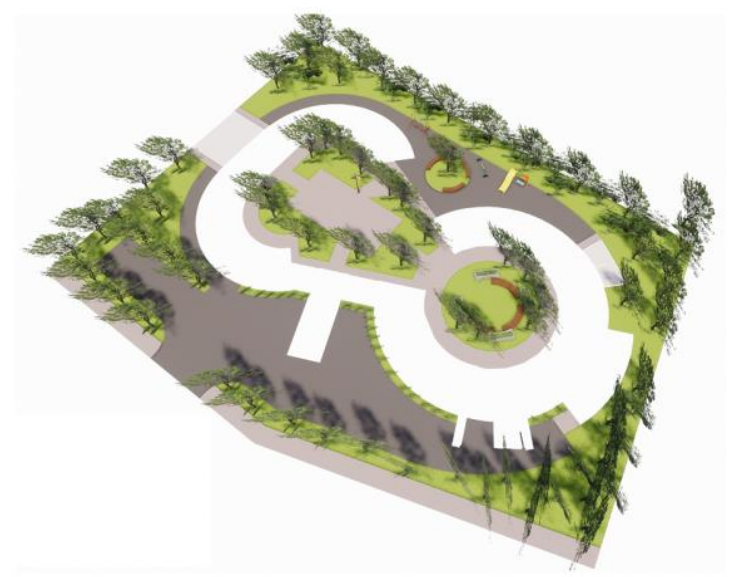

Gambar 9. Denah Landscape Sumber: Olahan Penulis (2020)

Bangunan dikelilingi oleh banyaknya penghijauan, bentuk bangunan yang merupakan lingkaran menjadi salah satu alasan untuk mendapatkan sirkulasi pengudaraan alami yang baik pada setiap ruangan. Lingkaran dalam pada bangunan berfungsi untuk taman, selain berguna untuk sirkulasi pengudaraan alami yang baik juga berguna sebagai tempat anak-anak dapat berkumpul. Bentuk lingkaran juga memberi kesan kebersamaan dan merasa dilindungi dari bentuknya yang melingkar. Sehingga anak-anak tersebut dapat merasakan kenyamanan seperti rumah pada bangunan Rumah Belajar ini. 

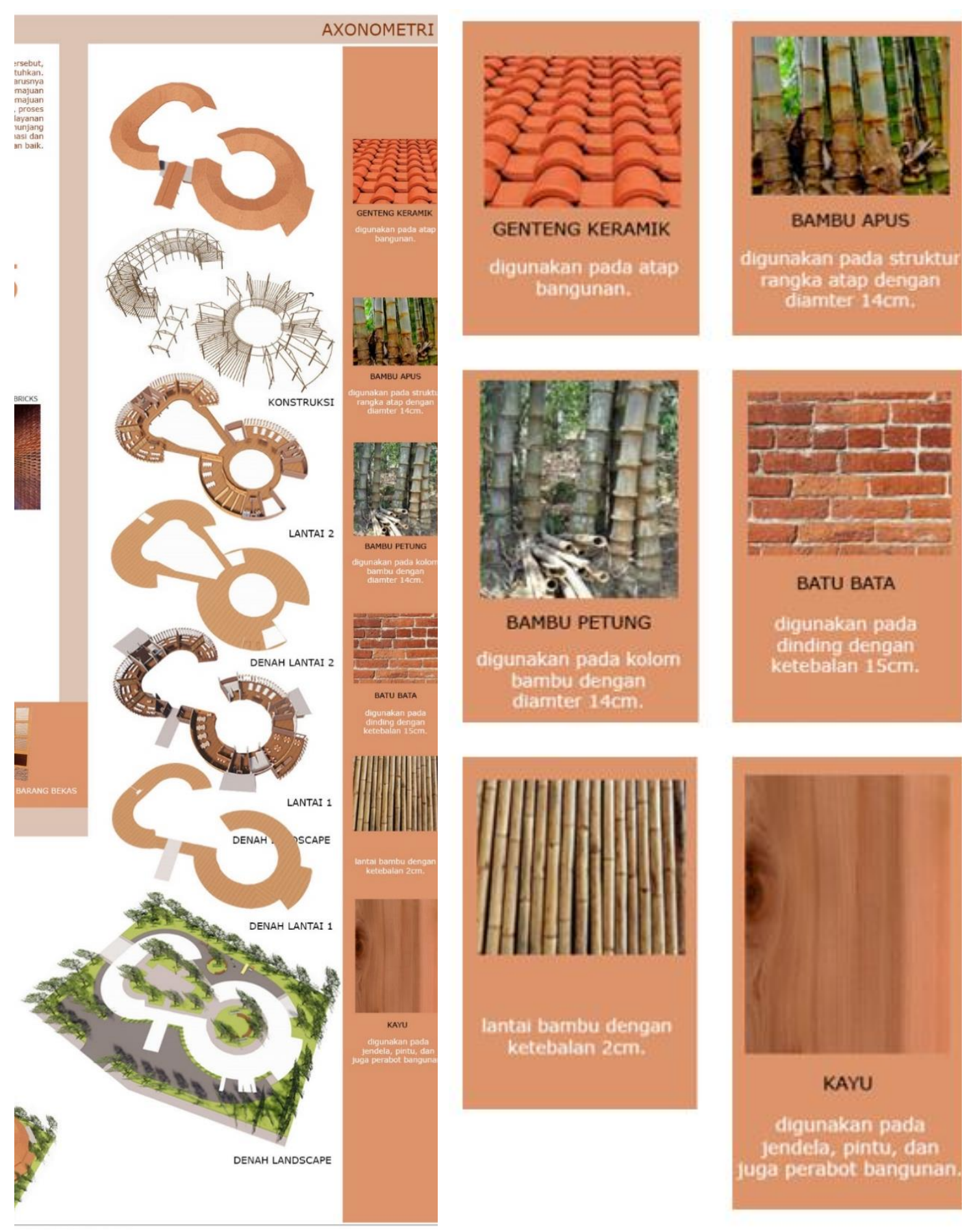

Gambar 10. Axonometri dan Material

Sumber: Olahan Penulis (2020)

Penggunaan material yang berkelanjutan dan ramah lingkungan pada bangunan:
Atap (Pelana)
: Genteng.
Lantai
: Bambu.
Konstruksi Bangunan : Bambu.
Perabot
: Kayu dan bambu.
Dinding
: Batu bata.
Pintu dan Jendela: Kayu dan bambu. 


\section{KESIMPULAN}

Rumah Belajar dalam konteks dwelling terkait berhuni di masa depan, mengangkat sebuah isu, yaitu kurangnya fasilitas pendidikan khususnya bagi anak-anak yang kurang mampu di kawasan Pademangan Barat. Rumah Belajar merupakan rumah kedua bagi anak-anak, di mana mereka menghabiskan keseharian waktunya dan juga sebagai tempat untuk melayani sejumlah tujuan dalam kehidupan seorang anak. Seperti belajar, bertukar pikiran, ide, perasaan dan menerima sebuah nilai-nilai umum. Dalam Rumah Belajar ini anak-anak berpeluang untuk menemukan tempat mereka di dunia ini melalui pencapain makhluk hidup terkait dengan dwelling. Konsep dari Rumah Belajar ini adalah menetapkan kehidupan dan sistem yang berkelanjutan, sehingga pengguna dalam Rumah Belajar ini dengan menjalankan tujuan dalam berhuni, namun pada bangunan dalam konteks arsitektur yang menetapkan sistem dan penggunaan material yang berkelanjutan yang dapat membantu untuk kehidupan di masa depan. Proyek ini bertujuan untuk merancang sebuah wadah bagi anak-anak yang kurang mampu di kawasan Pademangan Barat berupa Rumah Belajar. Rumah belajar ini merupakan sarana pendidikan non-formal setingkat sekolah dasar yang sekaligus menjadi wadah berkumpul bersama bagi anak-anak dalam mengembangkan kebersamaan serta peningkatan kualitas kehidupan mereka.

\section{REFERENSI}

Azwar, S. (2003). Sikap Manusia, Teori dan Pengukurannya. Yogyakarta: Pustaka Pelajar.

Apollo. (2019). Kajian Literatur Heidegger "Ada, dan Waktu" (Sein und Zeit). https://www.kompasiana.com/balawadayu/5e0acebdd541df37e65d4295/kajian-literaturheidegger- ada-dan-waktu-sein-und-zeit?page=all

Baquedano-Lopez, P., Alexander, R. A., \& Hernandez, S. J. (2013). Equity Issues in Parental and Community Involvement in Schools. Review of Research in Educatio, 37, 149-182.

Blank, M., Jacobson, R., \& Melaville, A. (2012). Achieving Result Through Community School Partnerships. Washington, DC: Center for American Progress.

Castrechini, S., \& London, R. A. (2012). Positive Student Putcones in Community Schools. Washington, DC: Center of America Progress.

Coombs. Philip H., Ahmed, Manzcor. (1985). Memerangi Kemisidnan di Peaesaan Melalui Pendidikan Non - Formal. Jakarta: CV. Rajawali

Djatnika, D. (2009). Peranan Pendidikan Dalam Pengentasan Kemiskinan. Jurnal IImu Administrasi dan Kebijakan Publik. 6(1), 1-12.

Heidegger, M. (1962). Being and Time. Oxford: Basil Blackwell.

Heidegger, M. (1971). Building, Dwelling, Thinking. New York: Harper Colophon Books.

Ingold, T. (2000). The Perception of the Environment. London: Routledge.

Norberg-Schulz, C. (1985). The Concept of Dwelling. New York: Rizzoli International Publication, INC. Zen.

Memahami Rumah. https://www.panditfootball.com/editorial/169147/ZRS/150116/memahami-rumah

Sachs, J. (2005). The End of Poverty. New York: Penguin Press.

Sennett, R. (2018). Building and Dwelling. Great Britain: Penguin Books.

Soelaiman, J. (2004). Konsep Dasar Pendidikan Luar Sekolah. Jakarta: PT Bumi Aksara.

Syah, M. (2004). Psikologi Belajar. Bandung: Grafindo Persada.

TMT Studio LTD. (2017). Is Self-sustaining, Off-grid Housing the Future of Sustainable Neighbourhoods? 